\title{
Clinical Significance of Neonatal Lenticulostriate Vas- culopathy: Association with Congenital Cytomegalovirus Infection
}

Kyungwon Park, Hyunsoo Kim, Sun Young Ko, Son Moon Shin, Yeon Kyung Lee, and Byung Hee Han* Departments of Pediatrics and Radiology*, Cheil General Hospital and Women's Healthcare Center, Dankook University College of Medicine, Seoul, Korea

\section{ABSTRACT}

Purpose: To investigate clinical characteristics of neonates with lenticulostriate vasculopathy (LSV) and determine the correlation between LSV and clinical characteristics, especially congenital cytomegalovirus (CMV) infection.

Methods: We retrospectively reviewed the medical records of neonates with LSV, born at Cheil General Hospital between January 2005 and December 2015. LSV was graded into three groups based on the number of the LSV lesions and classified into an isolated and combined group showing LSV with coexistent abnormalities noted on brain sonography. We compared clinical data based on the LSV classification.

Results: Our study included 102 neonates with LSV, which showed an unilateral pattern in 10 and bilateral pattern in 92 neonates. The numbers of neonates studied based on LSV grading were 33, 53, and 16 in grade 1, 2, and 3, respectively. We observed the isolated LSV in 62 and the combined type in 40 neonates. We observed that $93(91.2 \%)$ of the neonates with LSV did not show specific underlying cause for this condition. Congenital CMV infection was detected in 7 neonates, including 0 , 5 , and 2 neonates belonging to grade 1, 2, and 3, respectively. Among these, 2 neonates showed the isolated, and 5 showed the combined type of LSV. Statistically, congenital CMV infection was more significantly associated with LSV in grade 2 and 3 than in grade $1(P<0.05)$. Additionally, congenital CMV infection was more commonly observed in the combined than in the isolated LSV type showing a marginal association $(P=0.07)$.

Conclusion: We observed that LSV was not clinically significant except when associated with CMV infection. We suggest that neonates presenting with a grade 2 or higher of LSV or a combined type of LSV detected via neonatal brain ultrasonography should be evaluated for CMV infection.

Key Words: Lenticulostriate vasculopathy, Cytomegalovirus, Neonate
Received: 13 July 2017

Revised: 12 September 2017

Accepted: 23 September 2017

Correspondence to: Yeon Kyung Lee Department of Pediatrics, Cheil General Hospital and Women's Healthcare Center, Dankook University College of Medicine, 17, Seoae-ro 1-gil, Jung-gu, Seoul 4619, Korea

Tel: +82-2-2000-7771

Fax: +82-2-2000-7789

E-mail: ykleeped@hanmail.net

Copyright(c)

By Korean Society of Neonatology.

All right reserved.

This is an Open-Access article distributed under the terms of the Creative Commons Attribution Non-Commercial License (http://creativecommons.org/licenses/ by-nc/4.0), which permits unrestricted non-commercial use, distribution, and reproduction in any medium, provided the original work is properly cited. 


\section{서론}

Lenticulostriate vasculopathy (LSV)는 신생아의 뇌초음파 검사에 서 기저핵(basal ganglia) 혹은 시상(thalamus) 부위에 선형 또는 분 지형으로 음영이 증가된 형태를 의미한다 ${ }^{1,2)}$. 주로 기저핵과 시상으 로 주행하는 lenticulostriate 동맥에서 관찰되며, 신경병리학적으로 동맥벽에 호염구성 세포들이 응집되어 형성된 과세포성 침착물로 알려져 있어 mineralizing vasculopathy라고도 불린다 ${ }^{2)}$. LSV의 유병 률은 전체 출생아의 $0.27-2.5 \%$, 미숙아에서 $3.2-5.1 \%$, 치료받은 신 생아에서 1.9-5.8\%로 알려져 있다 ${ }^{3)}$.

$\mathrm{LSV}$ 의 원인은 크게 감염성과 비감염성으로 나눌 수 있는데 가장 흔한 감염성 원인으로는 거대세포바이러스(cytomegalovirus, CMV) 감염증이 있고 비감염성 원인으로 신생아가사, 저산소성 허혈성 뇌 병증, 허혈성 뇌경색, 염색체 이상 등이 있다 ${ }^{4)}$. 그 외에 특별한 원인 이나 기저 질환 없이 건강한 신생아에서도 많이 발견되고 있다 ${ }^{5,6)}$.

$\mathrm{LSV}$ 에 관련된 감염성 원인 중 하나인 선천성 CMV 감염은 자궁내 감염 및 선천성 바이러스 감염 중 가장 흔한 원인으로 출생아 중 $1 \%$ 미만의 유병률을 보이고 CMV의 혈청학적 유병률이 높은 지역에선 $2 \%$ 까지, 낮은 지역에선 $0.5-1 \%$ 로 보고되고 있다 ${ }^{7-9)}$. CMV 감염의 신 경영상의학적 소견은 LSV 외 두개내 뇌실주위 석회화, 뇌실확장증 등이 있다 ${ }^{10,11)}$

LSV가 보고된 이래, 지금까지 LSV의 원인 및 임상적 의의에 대한 많은 보고가 있었으나, 국내에서의 연구는 거의 없는 실정이다. 따 라서 본 연구는 신생아의 뇌초음파에서 발견되는 LSV와 연관된 임 상적인 특징들에 대해 알아보고, 특히 선천성 거대세포바이러스 감
염과 LSV의 연관성을 알아보고자 하였다.

\section{대상 및 방법}

2005년 1월 1일부터 2015년 12월 31일까지 단국의대 제일병원에 서 출생한 모든 신생아 중 뇌초음파에서 LSV가 확인된 102명을 대상 으로 아기와 산모의 의무기록을 본원의 임상연구윤리위원회의 승인 하에 후향적으로 연구하였다. 성별, 분만방식, 재태연령, 자궁내 성 장지연(출생체중 $<10 \mathrm{p}$ ), 소두증(머리둘레 $<10 \mathrm{p}$ ), 쌍생아, 아프가 점 수 등의 임상적 특징과 호흡곤란증후군, 선천성 심장병, 신생아 경 련, 선천성 CMV 감염(소변 polymerase chain reaction [PCR] 또는 배 양 검사에서 양성), 패혈증(혈액 배양 검사 양성), 저산소성 허혈성 뇌병증, 자동화 청성 뇌간반응 검사 이상, 선천성 기형의 이환 여부 를 조사하였다. CMV 평가는 전체 102례 중 90례에서 시행하였다.

영상의학적 검사 및 분석은 한 명의 소아영상의학과 전문의에 의 해 시행되었고, 뇌초음파는 35주 미만의 미숙아, 자궁내 성장지연 아, 소두증, 대두증(머리둘레 >90p), 무호흡증, 신생아 경련, 주산기 가사, 인공호흡기 치료, 산전 초음파상 이상 소견 등이 있을 때 시행 하였다. 뇌초음파 결과에서 LSV의 개수와 LSV 외 동반 병변의 유무 를 기준으로 분류하였다. LSV 병변 개수에 따라 3 개의 grade로 나누 었는데, 기저핵이나 시상 부위에 일측성 혹은 양측성에 관계없이 한 쪽에 1 개 보이는 경우 grade 1,2 개 보이는 경우 grade 2,3 개 이상 보 이는 경우 grade 3 으로 분류하였다(Figure 1). 또한 LSV 외에 동반된 소견의 유무에 따라 단독형(isolated) LSV, 복합형(combined) LSV로

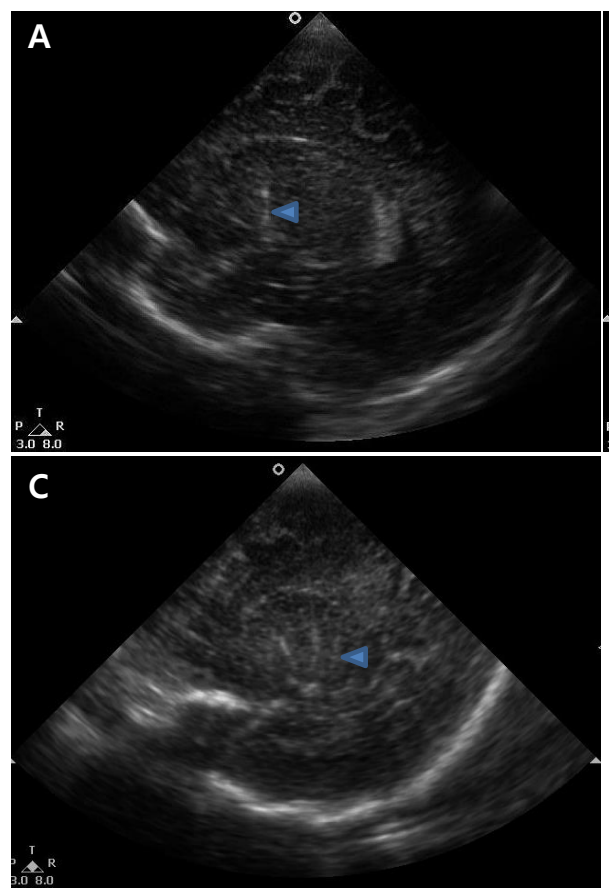

B

Figure 1. Grades of lenticulostriate vasculopathy. (A) Grade 1: one linear echogenic structure (arrowhead) (B) Grade 2: two linear echogenic structures (arrowhead) (C) Grade 3: three or more linear echogenic structures (arrowhead) in the basal ganglia or thalamus. 
분류하였다. 대상 환자에서 LSV의 영상의학적 분류에 따른 임상적 특징을 비교하였고, 선천성 CMV 감염 환자의 임상 경과와 LSV와의 연관성을 조사하였다.

자료 분석은 PASW Statistics for Windows, Version 18.0 (SPSS Inc., Chicago, TX, USA)를 이용하였고, 유의수준 0.05 미만일 경우 통계학적으로 유의한 것으로 간주하였다. 연속변수에 대해서는 평 균표표준편차로 표시하였고, 세 그룹(grade)에 대해서는 분산분석 (ANOVA)을, 두 그룹(grade)에 대해서는 $t$-검정을 시행하였다. 범주 형 변수에 대해서는 세 그룹, 두 그룹 비교시 각각 카이제곱 검정 및 우도비-카이제곱 검정을 시행하였다.

결과

\section{1. 대상 환자의 임상적 특징}

연구기간동안 11,167 명에서 머리 초음파를 시행하였고 이 중 LSV 소견을 보였던 신생아는 102 명으로 뇌초음파 검사에서의 발견율 은 $0.9 \%$ 였다. 이 중 91 명에서는 출생 후 1 주 이내에 4 명은 1 주에서 2

Table 1. Clinical Characteristics of Neonates with Lenticulostriate Vasculopathy $(\mathrm{n}=102)$

\begin{tabular}{lc}
\hline Characteristics & Values \\
\hline Gender & \\
Male & $45(44.1)$ \\
Female & $57(55.9)$ \\
Delivery type & \\
Vaginal delivery & $45(44.1)$ \\
Cesarean section & $57(55.9)$ \\
Gestational age (wks) & $37.3 \pm 3.4$ \\
Preterm & $27(26.5)$ \\
Term & $75(73.5)$ \\
Body weight (g) & $3,009.9 \pm 907.5$ \\
Small for gestational age & $5(4.9)$ \\
Microcephaly & $6(5.9)$ \\
Twin & $13(12.7)$ \\
Apgar score 1-min $<7$ & $28(27.5)$ \\
Apgar score 5-min $<7$ & $5(4.9)$ \\
Respiratory distress syndrome & $12(11.8)$ \\
Hypoxic ischemic encephalopathy & $0(0.0)$ \\
Neonatal seizure & $2(2.0)$ \\
Congenital cytomegalovirus infection & $7(7.8)$ \\
Congenital heart disease & $2(2.0)$ \\
Congenital anomaly & $3(2.9)$ \\
Abnormal AABR & $1(0.8)$ \\
\hline &
\end{tabular}

Values present mean \pm standard deviation, or number $(\%)$. Abbreviation: AABR, automated auditory brainstem response.
주 사이, 5 명은 2 주에서 4 주 사이에 발견되었다. 인구학적 특징상 남 아 45명, 여아 57명이었고, 질식분만 45 명, 제왕절개 57명으로 성별 및 분만 방식간에는 큰 차이는 없었고, 평균 재태연령은 $37.3 \pm 3.4$ 주 로, 미숙아가 27 명, 만삭아가 75 명이었다. 평균 출생체중은 3,009.9 $\pm 907.5 \mathrm{~g}$ 으로, 이 중 자궁내 성장지연아가 5 례였다. 1 분 또는 5 분 아 프가 점수가 7점 미만인 경우가 28례 있었고 소두증이 6례 있었다. 이환된 질환으로 호흡곤란증후군 12 례, 심실중격결손, 대동맥축착 의 선천성 심장질환이 2 례 있었고 신생아 경련 2례, 선천성 $\mathrm{CMV}$ 감 염 7례, 자동화 청성 뇌간반응 검사 이상이 1 례 있었고 선천성 기형 은 3례로 각각 말굽콩팥(horse-shoe kidney), Down 증후군, 구개열 이 동반되었다. 다른 선천성 감염이나 저산소성 허혈성 뇌병증, 신 생아가사, 허혈성 뇌경색, 쌍생아간 수혈증후군, 태아알코올증후군, 태아수종은 없었고, 특별한 원인 없이 발견된 사례가 93례(91.2\%)였 다(Table 1).

\section{LSV 분류에 따른 임상적 특성 비교}

LSV는 일측성이 10 례, 양측성이 92례였으며 병변 개수에 따른 분 류에서 grade 1, grade 2, grade 3는 각각 33례(32.3\%), 53례(52.0\%), 16 례(15.7\%)였고, 단독형이 62례(60.8\%), 복합형이 40례(39.2\%) 였다. 복합형 LSV에서 LSV 외 동반된 병변은 낭성 배아바탕질 출 혈(cystic germinal matrix hemorrhage)이 16례로 가장 많았고, 심 실 주위 음영 증가(periventricular echogenicity) 13례, 뇌부종 6례, 뇌실막밑 낭종(subependymal cyst) 5례, 뇌실확장증, 백질질환 각 각 2 례, 양측 대뇌반구내 심실주위 석회화, 좌측 기저핵 국소 허혈 성 병변, 좌측 시상에 출혈성 병변, 뇌실사이중격강(cavum septum pellucidum)이 각각 1 례씩 동반되었다. LSV의 각각의 grade에 따른 임상적 특성의 비교에서 선천성 $\mathrm{CMV}$ 감염을 제외하고 통계적으로 유의한 항목은 없었다(Table 2).

\section{LSV와 선천성 거대세포바이러스 감염과의 연관성}

전체 LSV 102례 중 90례에서 CMV 평가하였고 이 중 선천성 CMV 감염은 7례였다. grade 1 에서는 없었으며 grade 2에서 5례, grade 3 에서 2례, 그리고 단독형과 복합형 에서 각각 2 례와 5 례에서 발견되 었다. CMV 감염은 grade 1 보다 grade 2 이상에서 유의하게 많았고 $(P<0.05)$, 단독형에 비해 복합형에서 많았으나 통계적 의미는 없었 다 $(P=0.074$, Table 2$)$. 동일 기간 선천성 $\mathrm{CMV}$ 감염은 총 23 명 진단되 었고 이 중 $30.4 \%$ 에서 LSV가 동반되었다. 선천성 CMV 감염으로 진 단되었던 7례를 살펴보면 7례 모두 재태연령 37주 이상의 만삭아였 고 남아 5례, 자궁내성장지연이 3례, 소두증 2례 있었으며, 맥락망막 염 등의 안과적 문제는 없었다. 자동화 청성 뇌간반응 검사 이상이 1 례에서 발견되었으나 추적 검사한 청성 뇌간반응 검사는 정상이였 다. ganciclovir 치료를 받은 선천성 CMV 감염증 환자는 2 명으로 한 명은 혈소판 감소증, 자궁내 성장지연, 간비장비대와 LSV외 뇌실주 
Table 2. Radiologic Pattern of Lenticulostriate Vasculopathy and Clinical Features

\begin{tabular}{|c|c|c|c|c|c|c|c|c|c|}
\hline & $\begin{array}{c}\text { Total } \\
(n=102)\end{array}$ & $\begin{array}{c}\text { Grade } 1 \\
(n=33)\end{array}$ & $\begin{array}{c}\text { Grade } 2 \\
(n=53)\end{array}$ & $\begin{array}{c}\text { Grade } 3 \\
(n=16)\end{array}$ & $P$-value & $P$-value* & $\begin{array}{c}\text { Isolated } \\
(n=62)\end{array}$ & $\begin{array}{c}\text { Combined } \\
(\mathrm{n}=40)\end{array}$ & $P$-value \\
\hline \multicolumn{10}{|l|}{ Gender } \\
\hline Female & 57 & 21 & 28 & 8 & & & 34 & 23 & \\
\hline \multicolumn{10}{|l|}{ Gestational age } \\
\hline Preterm & 27 & 12 & 12 & 3 & 0.280 & 0.117 & 12 & 15 & 0.072 \\
\hline SGA & 5 & 4 & 1 & 0 & 0.393 & 1.000 & 2 & 3 & 0.613 \\
\hline A/S $1-\min <7$ & 28 & 9 & 15 & 4 & 0.967 & 1.000 & 11 & 17 & 0.012 \\
\hline A/S 5-min $<7$ & 5 & 0 & 4 & 1 & 0.278 & 0.273 & 2 & 3 & 0.613 \\
\hline Congenital CMV infection & 7 & 0 & 5 & 2 & 0.151 & 0.017 & 2 & 5 & 0.074 \\
\hline Seizure & 2 & 0 & 2 & 0 & 0.389 & 1.000 & 1 & 1 & 1.000 \\
\hline
\end{tabular}

* $P$-value: grade 1 vs. grade 2 and 3.

Abbreviations: SGA, small for gestational age; A/S, Apgar score; CMV, cytomegalovirus; CHD, congenital heart disease.

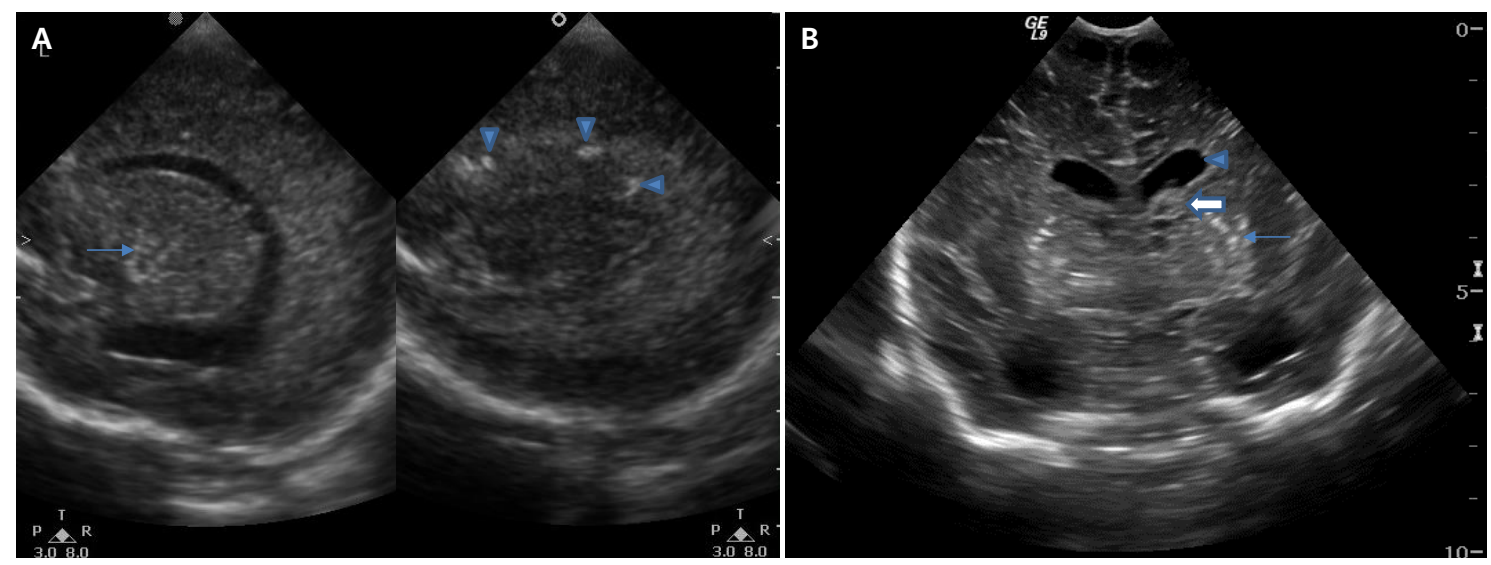

Figure 2. Lentriculostriate vasculopathy with combined lesions in congenital cytomegalovirus infection. (A) Case 1, Lenticulostriate vasculopathy (arrow) and periventricular calcifications (arrowhead). (B) Case 2, Lenticulostriate vasculopathy (arrow) and ventriculomegaly (arrowhead) and cystic germinal matrix hemorrhage (blank arrow).

위 석회화가 있으면서 소두증이 동반되어 중추신경계 감염이 의심 되었고 이 환자의 LSV는 grade 2, 복합형이었다(Figure 2). 다른 한 명은 혈소판 감소증, 자궁내 성장지연이 있었으며 LSV는 grade 2 , 단 독형이었다(Table 3).

\section{고찰}

$\mathrm{LSV}$ 는 신생아의 뇌초음파 검사에서 기저핵 혹은 시상으로 주행하 는 동맥에 선형 또는 분지형으로 음영이 증가된 형태를 의미한다 ${ }^{1,2)}$.
LSV가 있는 혈관은 중대뇌동맥에서 기시하는 외측 lenticulostriate 동맥과 전대뇌동맥에서 기시하는 내측 lenticulostriate 동맥이 대표 적이다 ${ }^{1)}$. 신경병리학적으로 동맥벽에 호염기성 세포들이 응집되 어 침착물을 형성하기에 mineralizing vasculopathy라고도 불린다 ${ }^{2)}$. Rumack와 Johnson ${ }^{12)}$ 에 의해 CMV 감염증에 동반된 기저핵의 석회 화가 1983년에 처음 발견된 후, Grant 등 ${ }^{13)}$ 이 선천성 CMV 감염증 미 숙아의 뇌초음파에서 LSV를 처음으로 보고하였다. 1988년 Teele 등 ${ }^{2)}$ 은 뇌초음파상의 LSV를 병리학적으로 확인하였으며, CMV, 풍진, 매독을 포함한 선천성 감염증 12 례를 보고하였다. 이후 CMV 감염을 제외한 다른 선천성 감염에 의한 LSV의 보고보다는 주산기 뇌손상 
Table 3. Cases of Congenital CMV Infection with Lenticulostriate Vasculopathy ( $\mathrm{n}=7$ )

\begin{tabular}{|c|c|c|c|c|c|c|c|c|c|c|c|c|}
\hline Case & $\begin{array}{c}\text { GA } \\
\text { (wks) }\end{array}$ & $\begin{array}{l}\text { Bwt. } \\
\text { (g) }\end{array}$ & $\begin{array}{c}\mathrm{HC} \\
(\mathrm{cm})\end{array}$ & Gender & $\begin{array}{l}\text { Delivery } \\
\text { type }\end{array}$ & $\begin{array}{l}\mathrm{A} / \mathrm{S} \\
\text { 1-min }\end{array}$ & $\begin{array}{c}\text { A/S } \\
\text { 5-min }\end{array}$ & $\begin{array}{l}\text { Thrombo } \\
\text { cytopenia }\end{array}$ & $\begin{array}{l}\text { Ganci } \\
\text { clovir }\end{array}$ & $\begin{array}{l}\text { Grades of } \\
\text { LSV }\end{array}$ & $\begin{array}{c}\text { Combined lesions } \\
\text { of LSV }\end{array}$ & Others \\
\hline 1 & $39^{+3}$ & $\begin{array}{l}2,375 \\
(<10 p)\end{array}$ & $\begin{array}{c}30 \\
(<10 \mathrm{p})\end{array}$ & Male & VD & 8 & 8 & + & + & 2 & $\begin{array}{l}\text { PV calcification both } \\
\text { Increased WM E } \\
\text { Cystic GMH left }\end{array}$ & \\
\hline 2 & $39^{+2}$ & $\begin{array}{l}2,785 \\
(25 p)\end{array}$ & $\begin{array}{c}33 \\
(45 p)\end{array}$ & Male & VD & 8 & 9 & - & - & 3 & $\begin{array}{l}\text { Cystic GMH both } \\
\text { Ventriculomegaly }\end{array}$ & cryptorchidism \\
\hline 4 & $39^{+5}$ & $\begin{array}{l}3,555 \\
(80 p)\end{array}$ & $\begin{array}{c}37 \\
(>90 \mathrm{p})\end{array}$ & Male & CS & 8 & 9 & - & - & 2 & $\begin{array}{l}\text { Cystic GMH right } \\
\text { Prominent CSP }\end{array}$ & $\begin{array}{l}\text { Abnormal } \\
\text { AABR }\end{array}$ \\
\hline 5 & $39^{+6}$ & $\begin{array}{l}2,810 \\
(40 p)\end{array}$ & $\begin{array}{c}33 \\
(40 \mathrm{p})\end{array}$ & Female & VD & 7 & 8 & - & - & 3 & Cystic GMH both & $\begin{array}{l}\text { hepatic } \\
\text { calc. }\end{array}$ \\
\hline
\end{tabular}

Abbreviations: GA, gestational age; Bwt, body weight; HC, head circumference; VD, vaginal delivery; CS, cesarean section; A/S, Apgar score; LSV, lenticulostriate vasculopathy; PV, periventricular; WM, white matter; E, echogenicity; GMH, germinal matrix hemorrhage; AABR, automated auditory brainstem response; CSP, cavum septum pellucidum.

을 일으킬 수 있는 비감염성 원인들로 인한 LSV와 그에 따른 신경발 달학적 예후에 대한 연구들이 있었다 ${ }^{4,14,15)}$. 최근에는 특별한 원인이 없이 건강한 신생아에서 발견되는 양성 소견으로서의 LSV를 많이 보고하고 있다 ${ }^{5,6,15)}$.

LSV의 병태생리학적 발생기전은 아직까지 정확하게 밝혀지지 않 았으며, 원인으로는 감염성, 비감염성, 특발성으로 분류하고 있다. 감염성 원인에는 톡소포자충증, 풍진, $\mathrm{CMV}$, 헤르페스, 매독, 수두 바이러스, 로타바이러스, 인간면역결핍바이러스 등이 있고, 비감염 성 원인으로는 주산기 뇌손상에 영향을 줄 수 있는 신생아가사, 저 산소성 허혈성 뇌병증, 허혈성 뇌경색, 염색체 이상, 신생아 루푸 스, 선천성 심장병, 쌍생아간 수혈증후군, 태아알코올 증후군, 태아 수종 등이 있다 ${ }^{4)}$. 그리고 특별한 원인 없이 건강한 신생아에서 우 연히 발견되는 특발성 LSV가 있다 ${ }^{5,6,15,16)}$. 본 연구에서는 특별한 기 저질환 및 원인 없이 발견된 경우가 93례로 가장 많았으며, 선천성 $\mathrm{CMV}$ 감염증이 7례, 이 중 2 례는 증상이 있는 선천성 CMV 감염으로 ganciclovir 치료를 받았다. 비감염성 원인 중 심실중격결손 1 례와 대동맥축착을 동반한 염색체 이상으로 Down 증후군 1 례 있었고, 저산소성 허혈성 뇌병증 및 허혈성 뇌경색 등은 없었다.

$\mathrm{LSV}$ 는 질병이 아닌 영상의학적 소견으로, LSV 자체가 기저 질환 의 진단 및 신경학적 예후를 위한 표지자가 될 수 있는지에 대해서 는 명확히 밝혀진 바가 없다. 아직까지 LSV의 진단에 있어 소아영상 의학과 의사들 사이에 표준화된 기준이 없으며, 그 중증도에 대한 분 류 기준도 정립된 바가 없다. 본 연구에서는 LSV의 개수와 LSV 외 동
반된 다른 초음파 소견의 유무에 따라 분류하여 LSV의 임상적 특징 들과 영상의학적 분류 사이의 연관성에 대해 알아본 결과, 선천성 $\mathrm{CMV}$ 감염과 1 분 아프가 점수 7 점 미만에서 연관성을 확인할 수 있 었다. 1 분 아프가 점수 7점 미만은 LSV 외 다른 소견이 동반되었을 경우에 단독형 LSV에 비해 유의하게 연관성을 보였는데 이는 미숙 아에서 아프가 점수가 다소 낮고, 뇌초음파에서 낭성 배아바탕질 출 혈, 심실 주위 음영 증가, 뇌실막밑 낭종과 같은 소견이 동반된 례가 많았기 때문으로 생각된다.

선천성 $\mathrm{CMV}$ 감염은 자궁내 감염 및 선천성 바이러스 감염 중 가 장 흔한 원인으로 출생아 중 $1 \%$ 미만의 유병률을 보이고, 대략 $10 \%$ 에서 출생시 소두증, 자궁내 성장지연, 간비장비대, 점상출혈성 발 진, 혈소판감소증, 출생시부터의 황달, 감각신경난청, 뇌염, 맥락망 막염, 발작, 용혈성 빈혈, 근육긴장저하 등의 증상을 보일 수 있다 ${ }^{8,9)}$. $\mathrm{CMV}$ 감염의 뇌 영상의학적 소견은 두개내 뇌실주위 석회화가 가 장 흔한 소견이며 다음으로 LSV, 백질질환, 뇌실확장증, migrational abnormalities, 뇌실주위 백질연화증 순이다 ${ }^{10,11)}$. LSV와 선천성 CMV 감염증과의 연관성에 대해서는 선천성 CMV 감염이 LSV의 원인 중 하나로 언급하는 많은 보고들이 있으나 LSV가 있을 때 CMV 평가에 대해서는 아직까지 확실하게 정립된 바가 없다. Cantey와 Sisman ${ }^{4)}$ 은 LSV가 있는 신생아들에게서 모든 선천 감염증에 대한 평가는 비 용대비 효율적이지 않지만, $\mathrm{CMV}$ 는 가장 흔하며 검사가 비침습적이 며 비싸지 않아 선별 평가가 필요하다고 하였다. 또한 LSV가 중추신 경계 감염의 예후 인자가 될 수 있다는 주장도 있는데, Duranovic 등 
${ }^{3)}$ 은 LSV가 두개내 감염의 비특이적 표지자이지만 소두증, 뇌실 주위 석회화, 청력 이상 등의 중추신경계 이상이 동반된 경우 LSV가 있는 모든 신생아들에게 CMV 검사가 필요하다고 하였다. Amir 등 ${ }^{17)}$ 은 선 천성 CMV 감염의 $54.3 \%$ 에서 LSV가 발견되었고, 이는 감각신경난 청의 표지자일 수 있다고 하였으며 Bilavsky 등 ${ }^{18}$ 도 LSV는 증상 있는 선천성 $\mathrm{CMV}$ 감염의 흔한 뇌초음파 소견으로 감각신경난청의 고위 험인자라고 하였다. 반면 De Jong 등 ${ }^{19}$ 에 따르면 다른 이상이 없는 LSV 에서는 CMV에 대한 선별검사가 비용대비 효율적이지 않다고 주장하였고, Hong 등이는 LSV 외 동반된 다른 뇌영상의학적 소견의 유무와 LSV의 크기에 따라 2단계로 나누어 LSV의 정도가 심하거나 다른 소견이 동반된 경우에 CMV 감염을 고려해야 한다고 하였다. 본 연구에서도 일측성 혹은 양측성으로 LSV가 1개 이하인 grade 1에 서는 선천성 $\mathrm{CMV}$ 감염증이 없었고, 일측성, 양측성에 관계 없이 한 쪽에 2개 이상의 LSV가 있을 경우에 선천성 CMV 감염증이 높았으 며, LSV 외 다른 소견이 동반된 경우가 단독형에 비해 선천성 CMV 감염증이 높은 경향을 보였다. 따라서 LSV 외 다른 동반된 소견이 없으면서 일측성 혹은 양측성으로 LSV 개수가 1 개 이하일 경우에는 $\mathrm{CMV}$ 검사가 필요하지 않을 것으로 생각되나 향후 이를 뒷받침할 수 있는 보다 많은 연구들이 시행되어야 할 것이다.

결론적으로, 본 연구에서 LSV는 대부분 특발성으로, 선천성 CMV 감염증 외에는 특별한 임상적 중요성을 찾을 수 없었다. 지금까지 본원에서는 LSV가 있는 신생아들에서 CMV 감염에 대한 검사를 진 행하였으나, 현재는 본 연구 결과에 근거하여 일측에 2 개 이상의 LSV가 있거나, LSV 외에 다른 동반 소견이 있을 경우에 CMV 선별검 사를 시행하고 있다. 하지만, 본 연구의 제한점으로는 모든 신생아 에게 뇌초음파를 시행할 수 없었고, LSV 모두에서 CMV 검사를 하지 못한 점과 LSV의 판독에 있어서 아직까지 명확한 기준이 없기에 뇌 초음파 검사자의 주관에 의존할 수 밖에 없는 점이다. 향후 LSV가 없 는 대조군과의 비교연구와 LSV의 진단 및 표준화된 분류 기준의 정 립이 필요할 것으로 생각된다.

\section{REFERENCES}

1) Koral K, Sisman J, Pritchard M, Rosenfeld CR. Lenticulostriate vasculopathy in neonates: perpective of the radiologist. Early Hum Dev 2015;91:431-5.

2) Teele RL, Hernanz-Schulman M, Sotrel A. Echogenic vasculature in the basal ganglia of neonates: a sonographic sign of vasculopathy. Radiology 1988;169:423-7.

3) Duranovic V, Krakar G, Mejaski-Bosnjak V, Lujic L, Gojmerac T, Marn B. Lenticulostriatal vasculopathy - a marker for congenital cytomegalovirus infection? Coll Antropol 2011;35 Suppl 1:14953.
4) Cantey JB, Sisman J. The etiology of lenticulostriate vasculopathy and the role of congenital infections. Early Hum Dev 2015;91:427-30.

5) El Ayoubi M, de Bethmann O, Monset-Couchard M. Lenticulostriate echogenic vessels: clinical and sonographic study of 70 neonatal cases. Pediatr Radiol 2003;33:697-703.

6) Leijser LM, Steggerda SJ, de Bruine FT, van Zuijlen A, van Steenis A, Walther FJ, et al. Lenticulostriate vasculopathy in very preterm infants. Arch Dis Child Fetal Neonatal Ed 2010;95:F426.

7) Kenneson A, Cannon MJ. Review and meta-analysis of the epidemiology of congenital cytomegalovirus (CMV) infection. Rev Med Virol 2007;17:253-76.

8) Britt WJ. Cytomegalovirus. In: Kliegman RM, Stanton BF, Geme III JW, Schor NF, Behrman RE, editors. Nelson textbook of pediatrics. 20th ed. Philadelphia: Elsevier Saunders, 2015:1590-4.

9) Harrison GJ. Cytomegalovirus. In: Cherry JD, Harrison GJ, Kaplan SL, editors. Feigin and Cherry's textbook of pediatric infectious diseases. 7th ed. Philadelphia: Elsevier Saunders, 2014:1969.

10) Fink KR, Thapa MM, Ishak GE, Pruthi S. Neuroimaging of pediatric central nervous system cytomegalovirus infection. Radiographics 2010;30:1779-96.

11) Boppana SB, Fowler KB, Vaid Y, Hedlund G, Stagno S, Britt WJ, et al. Neuroradiographic findings in the newborn period and long-term outcome in children with symptomatic congenital cytomegalovirus infection. Pediatrics 1997;99:409-14.

12) Rumack CM, Johnson ML. Role of CT and ultrasound in neo natal brain imaging. J Comput Tomogr 1983;7:17-29.

13) Grant EG, Williams AL, Schellinger D, Slovis TL. Intracranial calcification in the infant and neonate: evaluation by sono graphy and CT. Radiology 1985;157:63-8.

14) Shin HJ, Kim MJ, Lee HS, Namgung R, Park KI, Lee MJ. Imaging patterns of sonographic lenticulostriate vasculopathy and correlation with clinical and neurodevelopmental outcome. J Clin Ultrasound 2015;43:367-74.

15) Sisman J, Rosenfeld CR. Lenticulostriate vasculopathy in neonates: Is it a marker of cerebral insult? Critical review of the literature. Early Hum Dev 2015;91:423-6.

16) Lim SM, Lee MH, Kim HN, Baek SY, Lee SW. Lentriculostriate vasculopathy of brain ultrasonography. J Korean Radiol Soc 1997;36:899-904.

17) Amir J, Schwarz M, Levy I, Haimi-Cohen Y, Pardo J. Is lenticulostriated vasculopathy a sign of central nervous system insult in infants with congenital CMV infection? Arch Dis Child 2011; 96:846-50.

18) Bilavsky E, Schwarz M, Pardo J, Attias J, Levy I, Haimi-Cohen $\mathrm{Y}$, et al. Lenticulostriated vasculopathy is a high-risk marker for hearing loss in congenital cytomegalovirus infections. Acta 
Paediatr 2015;104:388-94.

19) De Jong EP, Lopriore E, Vossen AC, Steggerda SJ, Te Pas AB, Kroes $\mathrm{AC}$, et al. Is routine TORCH screening warranted in neonates with lenticulostriate vasculopathy? Neonatology 2010;97:274-8.
20) Hong SY, Yang JJ, Li SY, Lee IC. Lentriculostriate vasculopathy in brain ultrasonography is associated with cytomegalovirus infection in newborns. Pediatr Neonatol 2015;56:408-14. 